\title{
MANUAL THERAPY AND INTERACTIVE ELECTRO NEUROMODULATION IN THE TREATMENT OF SPASTICITY: EVALUATION OF IMMEDIATE EFFECTS
}

\author{
G.Barassi ${ }^{1}$, R.G. Bellomo², G. Melle ${ }^{3}$, G.Giannuzzo ${ }^{1}$, R. Saggini ${ }^{4}$ \\ 1 Section of Physical Medicine and Rehabilitation “G. D'Annunzio" University, Chieti, Italy \\ 2 Department of Medical Sciences, Oral and Biotechnology "G. D'Annunzio" University, Chieti, Italy \\ 3 School of Specialties in PRM, "G. D'Annunzio" University, Chieti, Italy \\ 4 Section of Physical Medicine and Rehabilitation G. D'Annunzio" University, Chieti, Italy
}

This study, underwent in the Chair of Physical Medicine and Rehabilitation of "G. d'Annunzio" University of Chieti-Pescara, have the purpose to evaluate the immediate effects on spasticity of lower limbs of two different therapeutic approaches on a single session in patients affected by cerebral palsy. 30 patients has been recruited and divided in 3 groups: Group A has been treated with neuromuscular manual therapy in acquatic environment.

Group B has been treated with interactive electro neuromodulation. Group $\mathrm{C}$ has underwent sham approach respecting the operative procedure of Group B treatment. The whole sample has been recruited following these inclusion criteria:

Diagnosis of cerebral palsy

Age between and 10-20 years

Presence of spastic para/tetra paresis

Ashworth Scale result between 1 and 3

The whole sample has been evaluated using a myometric system, MyotonPro, before (T0) and after (T1) the single session of treatment, in the same environmental conditions. The statistical analysis underline that both Interactive Electro Neuromodulation and Manual Therapy in Water Environment results effective in reduction of muscular tone, while in Group $\mathrm{C}$ no significant results has been shown. In conclusion, we can affirm that Interactive Electro Neuromodulation approach could be a good alternative for the treatment of spasticity in patients affected by cerebral palsy, regarding costs and benefits.

\section{REFERENCES}

1) Bax M, Goldstein M, Rosenbaum P, Leviton A, Paneth N, Dan B, Jacobsson B, Damiano D; Executive Committee for the Definition of Cerebral Palsy. Proposed definition and classification of cerebral palsy, Dev Med Child Neurol. 47, 571-6 (2005).

2) Lance JW: Symposium sinopsi, in Feldman RG, Young RR, Koella WP(ed): Spasticity: disordered motor control Chicago, Year Book Medical Publishers, 1980.

3) Clark SL, Hankins GD. Temporal and demographical trends in cerebral palsy ? fact and fiction. Am J Obstetrand Gynecol 2003;188:628-33

4) Pollock GA: Lengthening of the Gastrocnemius Tendon in Cases of Spastic Equinus Deformity. J Bone Joint Surg 358:148, 1.953

5) Mayston M (2004). Physiotherapy management in cerebral palsy: an update on treatment approaches. Clinics in Developmental Medicine (161) pp : 147-160.

6) Dodd KJ, Taylor NF, Damiano DL. (2002) A systematic review of effectiveness of strength-training programs for people with cerebral palsy. Arch Phys Med Rehabil 83: 1157? 1164

7) Dumas H, Francesconi S. (2001) Aquatic therapy in pediatrics: annotated bibliography. Phys Occup Ther Pediatr 20: 63?79

8) Kelly, M., \& Darah, J. (2005). Aquatic exercise for children with cerebral palsy. Developmental Medicine \& ChildNeurology, 47, $838 ? 842$

9) Irion, J.M. (2009). Aquatic properties and therapeutic interventions In: L. T. Brody, P.R. Geigle (Eds), Aquatic exercise for rehabilitation and training (pp. 25-34). Champaign: Human Kinetics.

10) Prins, J.H. (2009). Aquatic rehabilitation. Serbian Journal of Sports Sciences, 3(1-4), $45-51$.

11) Lepore, M. (2005). Aquatics. In: J.P. Winnick (Ed.), Adapted Physical education and Sport (pp.435-454). Champaign: Human Kinetics.

12) Daly, D., \& Lambeck, J. (2007). New trends in adapted swimming. In Colomina R., Molina J., Valdivieso F., Ortiz E., Contreras G. (Eds.), Swimming science I (pp. 19-30). Granada, Spain: Editorial Universidad de Granada 